\title{
Endometrial Hiperplazi ve Karsinomunda Nükleus Boyutunun Karşılaştırmalı Morfometrik Analizi
}

\section{Comparative Morphometric Analysis of Nucleus Size in Endometrial Hyperplasia and Carci- noma}

\author{
${ }^{1}$ Ayşe Nur UĞUR KILINÇ, ${ }^{2}$ Sıddıka FINDIK, ${ }^{2}$ Pembe OLTULU \\ ${ }^{1}$ Konya Research and Training Hospital, Pathology, Konya, Turkey \\ ${ }^{2}$ Necmettin Erbakan University Meram Medicine Faculty, Department of Pathology, Konya, Turkey \\ Ayşe Nur Uğur Kılınç: https://orcid.org/ 0000-0002-0439-0101 \\ Siddika Findık: https://orcid.org/ 0000-0002-3364-7498 \\ Pembe Oltulu: https://orcid.org/ 0000-0003-3273-671X
}

\section{ÖZ}

Amaç: Ülkemizde ve tüm dünyada sıklığı giderek artmakta olan endometrial karsinomların öncül lezyonları endometrial hiperplazilerdir. Histopatolojik özellikleri tanımlanmış olmasına rağmen kriterlerin objektif olmamas1 ve immünohistokimyasal tekniklerin sinırlı olmas1 hiperplazi olgularında gözlemciler arasında uyumsuzluk ortaya çıkarmaktadır.

Çalışmamızda atipili ve atipisiz endometrial hiperplazi ile atipili hiperplazi (EIN) ve Grade-I karsinomlarda gland epitel hücrelerinde en kısa nukleus çapı (NKÇ) ölçülerek gözlemciler arasındaki varyasyonlarını en aza indirmek için tanıya yardımcı olabilecek farklılık ve oran bulmayı amaçladık.

Materyal ve Metot: Çalışmamıza; küretaj ve histerektomi materyallerinde proliferatif endometrium, endometrial hiperplazi ve adenokarsinom tanısı almıs 100 vaka dahil edildi. Her bir olguda 50 adet gland epitel hücresi nükleuslarının en kısa çapı görüntü analiz programı ile (BAB Bs200Pro Image Analysis Software) manuel olarak ölçüldü.

Bulgular: İkili grupların karşılaştırılmasında EİN'in glandüler epitel NKÇ'si ile atipik hiperplazi (AH)'nin glandüler epitel NKÇ'si, AH'nin glandüler epitel NKÇ'si ile proliferatif endometirum (PE)'nin glandüler epitel NKÇ'si arasındaki karşılaştırmalar dışında, tüm ikili karşılaştırmalarda istatistiksel olarak anlamlı derecede farklılık bulunmuştur $(\mathrm{p}<0,01)$.

Sonuç: Çalışmamızda ortaya çıkan nükleus çapları ile ilgili oran ve kıyaslamaların rutin 1 şı mikroskobu ile histopatolojik incelemede ilave ekipman gerekmeden öngörülerde bulunduğu için pratik uygulamalarda faydalı olabileceğini düşünüyoruz.

Anahtar Kelimeler: Endometrial hiperplazi, endometrial intraepithelial neoplazi, morfometrik analiz

\section{ABSTRACT}

Objective: Endometrial hyperplasias are the preliminary lesions of endometrial carcinomas. Although the histopathologic features are well-defined, the criteria are not objective and the immunohistochemical techniques are limited, resulting in inconsistency between the observers in cases of hyperplasia. Our study aimed to measure and compare the shortest nuclear diameter (SND) of gland epithelial cells; to find differences and ratios that may help to minimize variations among observers.

Materials and Methods: Our study included 100 cases diagnosed as proliferative endometrium (PE), endometrial hyperplasia, and endometrioid carcinoma from their curettage and hysterectomy materials. For each case, the shortest diameter of 50 gland epithelial cell nuclei was manually measured with an image analysis program (BAB Bs200 Pro Image Analysis Software).

Results: Comparison of binary groups revealed that except the comparisons between glandular epithelial SNDM of EIN (endometrial intraepithelial neoplasia) and glandular epithelial SNDM of AH (atypical hyperplasia), and glandular epithelial SNDM of AH and glandular epithelial SNDM of PE all comparisons were statistically significantly different $(\mathrm{p}<0.01)$.

Conclusion: We think that the ratios and comparisons related to nucleus diameters obtained in our study may be useful in practical applications because predictions can be made with routine light microscopy and histopathological examination.

Keywords: Endometrial hyperplasia, endometrial intraepithelial neoplasia, morphometric analysis
Sorumlu Yazar / Corresponding Author:

Ayşe Nur Uğur Kılınç

Konya Training and Research Hospital, Pathology, Hacıșaban Mahallesi, Yeni Meram Cd. No: 97, 42090 Meram/Konya

Tel: +90 (332) 221-0000/2154

E-mail: aysenurugur@hotmail.com
Yayın Bilgisi / Article Info:

Gönderi Tarihi/ Received: 14/08/2020

Kabul Tarihi/ Accepted: 29/09/2020

Online Yayın Tarihi/ Published: 30/12/2020 


\section{INTRODUCTION}

Endometrium cancer is the fifth most common cancer in women, following breast, colorectal, cervical, and lung cancers, according to GLOBOCAN 2012 data, and is the eighth most common cause of cancer-related deaths. ${ }^{1}$ Endometrium cancer, which had a marked increase in incidence with the use of hormone replacement therapy at the beginning of the $1970 \mathrm{~s}$, declined to the incidence level seen in previous years in the 1980s. The incidence of endometrium cancer has been increasing since the mid-1980s due to factors such as the prolongation of life span, the application of postmenopausal estrogen replacement therapy, the development of regular examination habits, the development of early diagnostic methods, and early detection thanks to cervical cancer screening programs. A woman's lifelong endometrial cancer risk is known as $2-3 \%$. $^{2}$

Endometrial intraepithelial neoplasia is the precancerous lesion of endometrial cancer and has similar risk factors as endometrial cancer. ${ }^{3}$ Various classifications have been made for hyperplasias till today to diagnose them and plan appropriate treatments for them because they are precursors of endometrium cancer and they can be found simultaneously with cancer. In 1985 Kurman and Norris classified endometrial hyperplasias as simple or complex according to structural changes and with or without atypia according to their inclusion of cytological or nuclear atypia. This classification was accepted by the World Health Organization (WHO) in 1994 and its use became more widespread. ${ }^{4}$ However, a new classification was needed because the diagnostic criteria in the WHO 94 classification were subjective and therefore the reproducibility of the diagnosis and the compatibility between the diagnoses were low. Endometrial Collaborative Group defined classification for Endometrial Intraepithelial Neoplasias (EIN) in the early 2000s. ${ }^{4}$ WHO merged the last 2 classifications in 2014 and created the classification system.

The diagnosis of atypia in endometrial hyperplasia is made histomorphological. Nuclear atypia is characterized by enlargement in the nucleus, pleomorphism, rounding, loss of polarity, and nucleolus prominence. ${ }^{3}$ However, the diagnosis is difficult because the criteria of cytological atypia vary among the observers, there are cross-sectional and fixational defects, the degree of fragmentation is so high that it separates endometrial glands from stroma, and there are artifacts and endocervical tissue contaminations. This makes sometimes the differential diagnosis of simple hyperplasia and hyperplasia with atypia difficult. Although results that support diagnosis were reached in immunohistochemical studies the marker that can make the exact differentiation has not been detected yet. Therefore, morphological evaluation is still valid to make the differentiation between endometrial hyperplasia with or without atypia and between hyperplasia with atypia and endometrioid carcinoma (grade 1).

In our study, we aimed to find quantitative values and a rate that could help the diagnosis in proliferative endometrium, endometrial hyperplasia and endometrioid carcinoma (grade 1) cases by performing morphometric measurements.

\section{MATERIALS AND METHODS}

After obtaining the approval of the Ethics committee of Necmettin Erbakan Unıversity Meram Medical Faculty clinical research (Date: 2014/12/26, decision no: 2014/87).

Materials: In this study probe curettage materials sent to the pathology laboratory of Necmettin Erbakan University Meram Faculty of Medicine between 2009 and 2016 were viewed and categorized by a single observer. Qualified preparations were selected to obtain clear images. Preparations containing artifacts were not included in the study. Twenty five AH/EIN cases, 25 hyperplasia without atypia cases, 25 endometrioid carcinoma (grade 1) cases, and 25 proliferative endometrium cases were included in this study. All cases were selected from curettage materials except 2 adenocarcinoma cases; 2 adenocarcinoma cases were obtained from hysterectomy material. While evaluating our study, $98 \%$ of our materials are curettage materials and we tried not to include hysterectomy materials in our study because they contain artifacts due to cold ischemia.

Methods: All hematoxylin-eosin stained preparations were examined, and appropriate areas were identified. Using $40 \mathrm{X}$ objective of Pixera 150ESCU camera attached to an Olympus BX51 microscope photographs at various numbers were obtained including endometrial gland epithelial cells of each case from the marked areas. The shortest nucleus diameter (SND) of a mean number on 50 gland epithelial cells from each case were analy- 
zed manually using an image analysis software (BAB Bs200Pro Image Analysis Software).

Analyzes: Mean values were calculated for each case. Cells in overlapping, crush artifact, nucleus borders of which are not clearly visible, necrotic and inflamed areas were not included in the measurement.

Statistical Analysis: Statistical analyses were performed using SPSS (Statistical Package for Social Sciences) version 15.0. Mean, standard deviation (SD), and the ratio was used as descriptive statistics in quantitative data. A comparison between the groups was performed using the Kruskal Wallis analysis of variance test. To find the difference -making group the Mann Whitney U test with Bonferroni correction was performed. For all comparisons $\mathrm{p}<0.05$ was accepted as the significance level.

\section{RESULTS}

The shortest nucleus diameter of 50 gland epithelial cells of each case among the 100 cases included in this study was measured. The severity of the endometrial lesion increased as the shortest nucleus diameter mean (SNDM) increased. SNDM increased gradually in proliferative endometrium (4.31 \pm 0.64$)$, atypical hyperplasia (4.48 $\pm 0.59)$, AH / EIN (6.71 \pm 1.4$)$, and endometrioid carcinoma grade $1(7.8 \pm 1.5)$ reaching the highest. (Table 1) The Mann Whitney U test and the Kruskal Wallis test showed a statistically significant difference in all groups except atypical hyperplasia gland epithelium SNDM and endometrioid carcinoma gland epithelium SNDM and nontypical hyperplasia gland epithelium SNDM and proliferative endometrial gland epithelium SNDM (Fig 1, 2, $\underline{3}$ ).

The comparison of SNDM's according to the obtained results in this study showed that SNDM of hyperplasia with atypia was approximately 2 times $(1.89 \pm 0.60)$ higher than SNDM of normal proliferative endometrium (Table 2).

\section{DISCUSSION AND CONCLUSION}

Although pathology is a morphological science based on disease classifications, the importance of morphometric analysis in addition to qualitative evaluations is known for years. ${ }^{5}$ Detailed cytological and histological evaluations used to increase the reliability of grading includes variability among pathologists. Furthermore, the addition of misleading, versatile, and semi-quantitative meth- ods does not decrease this subjectivity. For this reason, objective and quantitative techniques should take the place of subjective and qualitative methods, increase repeatability, and improve inter -observer reliability. ${ }^{6-7}$ On the other hand, despite the rapidly advancing progress towards the molecular basis of cancer, the pathologist must first make morphological and morphometric structural assessments, As well as focus on the nuclear dimension that reflects nuclear anaplasia and the variations of the nuclear dimension in both cytological and histological examinations.

Nucleus diameter measurements have been made in different tissues in many studies until today. In the results of this study, nucleus diameters were associated with prognosis and tumor grade..$^{8-11}$ Morphometric analysis has been studied in the endometrium for many years and is still up-todate. ${ }^{12-17}$ In the morphometric analysis, single or multiple parameters have been used in studies carried out until today. ${ }^{18-20}$

In 2009 Malpica et al. defined the most important criteria for atypia as nucleus size, chromatin distribution, nucleolus prominence, and nuclear rounding. Because these criteria are subjective there is interobserver variability. ${ }^{13}$ Morphometric analysis in the endometrium becomes more important for these subjective criterias.

The first morphometric analysis was performed by E. Skarland in 1985 using cytological aspirates of 35 normal endometria and 20 good or moderately differentiated adenocarcinoma. The mean nuclear area was significantly higher in malign cells than normal epithelial cells. The authors tried to determine a cut-off value using numeric data and the most appropriate value was $45 \mu \mathrm{m}^{2}$. But this value yields $17 \%$ false positivity and $25 \%$ false negativity. ${ }^{14}$

Baak et al. evaluated 39 cases with endometrial hyperplasia in their study namely risk assessment in endometrial hyperplasias using morphological and morphometric features. Baak et al. studied 10 morphometric nuclear features includes perimeter (mean), perimeter (standard deviation), area (mean), area (standard deviation), shortest axis (standard deviation), longest axis (mean), longest axis (standard deviation), shape factor nuclei (mean), shape factor nuclei (standard deviation) and 12 morphometric glandular structural features; volume percentage stroma, volume percentage epithelium, volume percentage lumen, volume percentage glands, outer surface density glands, 
luminar surface density glands, length density glands, diameter glands, diameter lumina, thickness epithelium, shape factor glands, mean curvature lumina. They concluded that evaluating structural and nuclear properties together is of better prognostic importance than nuclear properties alone. Analysis of D score which is formed by 3 parameters (volume percentage stroma, outer surface density glands and standart deviation of shortest nuclear axis) which are the best prognostic factors among these 22 parameters gives significant results to predict progression to carcinogenesis from endometrial hyperplasia with atypia. ${ }^{15}$ Comparison of morphometric measurement results with morphological results showed that sensitivity was higher, and specificity was lower with morphometric D score analysis. As a result of this study, the authors concluded that atypical localization of the nucleus inside the epithelial cell which is included in morphological nuclear atypia definition but absent in morphometric parameters may be improved with a quantitative marker. $^{15}$

Although very significant results have been reached with morphometric D score analysis measurement in the endometrium, these studies aimed to detect cancer progression ${ }^{12,16}$ in hyperplasia variation and ratios among proliferative endometrium, hyperplasia without atypia, hyperplasia with atypia, and adenocarcinoma grade 1 were not evaluated. ${ }^{17}$ In the literature search, no publication was found that compared nucleus diameter measurements of hyperplasia with atypia, adenocarcinoma (grade 1), hyperplasia without atypia, and proliferative endometrium. Therefore, our study is the first one to evaluate such an analysis. In our study ratio of SNDM of hyperplasia with atypia to SNDM of proliferative endometrium was approximately 2; easy use of SNDM ratios in routine histopathology practice gives uniqueness to our study.

Another study on this subject was conducted in 2010 by Mahovlic et al. In their study of endometrial cytologic aspirate samples of 77 cases, they compared 9 nucleus parameters including SNDM in Papanicolau stains. They found significant differences in all parameters except the nucleus form factor and elongation factor (long diameter/short diameter) between malign hyperplastic and proliferative endometrium. ${ }^{17} \mathrm{As}$ in Mahovlic et al. study in the literature we also found differences between proliferative, hyperplasia without atypia, hyperplasia without atypia, and endometrioid carcinoma grade 1 groups.

In addition grade 1 endometrioid carcinoma and hyperplasia with atypia diagnoses may lead to diagnostic confusion in curettage materials where tissues are fragmented. No difference could be found in levels of nuclear atypia between these 2 groups and therefore, endometrioid carcinoma diagnosis should not be made if findings supporting endometrioid carcinoma are not seen architecturally in curettage material.

We measured the shortest nucleus diameters in our study because nuclei in endometrial glands which are normally oval and elongated become round due to atypia and so the shortest diameter reflects atypia better. In D score studies; One of the best prognostic values in the morphometric parameters studied was the standard deviation of the shortest nuclear axis

Limitations of our study include lack of some nuclear parameters like nucleus longest diameter (longest diameter/shortest diameter), form factor (nuclear irregularity) convex area, peripheral length, and area; and some glandular morphometric parameters that reflect glandular branching and frequency like gland-stroma ratio, and gland peripheral surface density $(4 \pi$ are $\div<2)$ and lack of other benign conditions (endometrial metaplasia, secretory endometrium etc.). More comprehensive studies will enrich the results by obtaining the results. There is also a need for studies to link the nucleus size to prognosis in endometrium carcinomas in long term studies.

According to the results of our study, endometrial glandular cell nuclei in endometrial curettage materials; Approximately 2 times larger than normal endometrial glandular cell nuclei should suspect atypia.

Ethics Committee Approval: Ethics committee approval was received for this study from the ethics committee of Necmettin Erbakan University Meram Medical Faculty Clinical Research (Date: 2014/12/26, decision no: 2014/87).

Conflict of Interest: No conflict of interest was declared by the authors.

Author Contributions: Concept- AUK, SF; Design - SF, AUK; Supervision- AUK; Resource PO, SF, AUK; Materials - PO, AUK; Data Collection and/or Processing - AUK; Analysis and / or Interpretation - AUK, SF; Literature Search AUK; Writing - AUK, SF; Critical Reviews - 
AUK, SF.

Peer-review: Externally peer-reviewed.

Acknowledgments: Authors thank Prof Dr. Osman Yilmaz, who contributed to planning the study.

\section{REFERENCES}

1. Ferlay J, Soerjomataram I, Ervik M, et al. GLOBOCAN 2012 v1. 0, Cancer incidence and mortality worldwide: IARC Cancer Base No. 11. Lyon, France: International Agency For Research On Cancer. 2012;11. doi:10.1002/ijc. 29210

2. Siegel R, Ma J, Zou Z, Jemal A. Cancer statistics. Cancer Journal For Clinicians. 2018;68(5):329-339. doi: 10.3322/ caac. 21208

3. Kurman RJ, Kaminsk PF, Norris HJ. The behavior of endometrial hyperplasia. A longterm study of "untreated" hyperplasia in 170 patients. Cancer. 1985;56(2):403-412.

4. Emons G, Beckmann MW, Schmidt D, Mallmann P. Uterus commission of the Gynecological Oncology Working Group (AGO). New WHO Classification of Endometrial Hyperplasias. Geburtshilfe Frauenheilkd. 2015;75(2):135-136. doi:10.1055/s0034-1396256

5. Collan Y. Diagnostic morphometry: Relevant background to decision making in diagnostic histopathology Science on Form: Proceedings of the First International Symposium for Science on Form. KTK Scientific Publishers, Tokyo. 1986;533-542.

6. Sørensen FB. Quantitative analysis of nuclear size for prognosis-related malignancy grading. Advances in Oncobiology. 1996;1:221255. doi :10.1016/S1569-254X(96)80013-6

7. Pell R, Oien K, Robinson M, et al. The use of digital pathology and image analysis in clinical trials. Journal of Pathological Clinical Research. 2019;5:81-90. doi:10.1002/ cjp2.127

8. Nunes T, Filippi-Chiela E, Callegari-Jacques $\mathrm{S}$, et al. Nuclear morphometric analysis in tissue as an objective tool with potential use to improve melanoma staging. Melanoma Research. 2019;29(5):474-482 doi: 10.1097/ CMR.0000000000000594
9. Yang W, Tian R, Xue T. Nuclear shape descriptors by automated morphometry may distinguish aggressive variants of squamous cell carcinoma from relatively benign skin proliferative lesions: A pilot study. Tumour Biology. 2015;36:6125-6131. doi: 10.1007/ s13277-015-3294-5

10. Hoque A, Lippman SM, Boiko IV, et al. Quantitative nuclear morphometry by image analysis for prediction of recurrence of ductal carcinoma in situ of the breast. Cancer Epidemiology, Biomarkers\&Prevention. 2001;10:249-259.

11. Vukovic LD, Jevtic P, Edens LJ, Levy DL. New insights into mechanisms and functions of nuclear size regulation. International Review of Cell and Molecular Biology. 2016;322:1-59. doi: 10.1016/ bs.ircmb.2015.11.001

12. Downing MJ, Papke DJ, Tyek S, Mutter GL. A New Classification of Benign, Premalignant, and Malignant Endometrial Tissues Using Machine Learning Applied to 1413 Candidate Variables. International Journal of Gynecological Pathology. 2020;39(4):333343. doi: 10.1097/PGP.0000000000000615

13. Malpica A, Michael TD, Euscher E. Biopsy interpretation of the uterine cervix and corpus. 1nd edition Lippincott Williams \& Wilkins, 2009; 177.

14. Skaarland E, Nuclear size and shape of epithelial cells from the endometrium: lack of value as a criterion for differentiation between normal, hyperplastic, and malignant conditions. Journal of Clinical Pathology. 1985;38(5):502-506. doi: 10.1136/ jcp.38.5.502

15. Baak JP, Nauta, JJP, Wisse-Brekelmans ECM, Bezemer PD. Architectural and nuclear morphometrical features together are more important prognosticators in endometrial hyperplasias than nuclear morphometrical features alone. The Journal of Pathology. 1988;154(4):335-341. doi: 10.1002/ path. 1711540409

16. Dunton CJ, Baak JP, Palazzo JP, van Diest PJ, McHugh M, Widra EA. Use of computerized morphometric analyses of endometrial hyperplasias in the prediction of coexistent cancer. American Journal Of Obstetrics And 
Gynecology. 1996;174(5):1518-1521. doi: 10.1016/s0002-9378(96)70599-9

17. Mahovlić V, Ovanin RA, Škopljanac ML, et al. Digital morphometry of cytologic aspirate endometrial samples. Collegium Antropologicum. 2010;34(1):45-51.

18. Toy H, Etli O, Celik ZE, Alikanoglu AS. Associations between nucleus size, and immunohistochemical Galectin-3, Cytokeratine-19 and Hbme1 markers in thyroid papillary carcinoma: a morphometric analyze. Pathology \& Oncology Research. 2019;25(1):401-408.

19. Deans GT, Hamilton PW, Watt PCH, et al. Morphometric analysis of colorectal cancer. Diseases of the Colon \& Rectum. 1993;36:450-456. doi: 10.1007/BF02050010

20. Celik ZE, Altinay S, Kilinc F, et al. Using Computerized Cytomorphometry to Distinguish between Benign and Malignant Cases in Thyroid Fine-Needle Aspiration Cytology. Diagn. Cytopathol. 2016;44:902-911. doi:10.1002/dc.23611 
Table 1. Qualitative data obtained as a result of the morphometric measurement.

\begin{tabular}{|l|c|c|c|}
\hline & $\begin{array}{c}\text { Average of se- } \\
\text { ries }\end{array}$ & $\begin{array}{l}\text { Smallest } \\
\text { number }\end{array}$ & Largest number \\
\hline Proliferative endometrium & $4.31 \pm 0.64$ & 2.4 & 5.9 \\
\hline Hyperplasia without atypia & $4.48 \pm 0.59$ & 3.34 & 5.7 \\
\hline AH/EIN & $6.1 \pm 1.4$ & 3.87 & 10.61 \\
\hline Endometrioid carcinoma (G- 1) & $7.8 \pm 1.5$ & 4.50 & 11.37 \\
\hline
\end{tabular}


Table 2. Rates obtained after morphometric measurement.

\begin{tabular}{|l|l|}
\hline Endometrioid carcinoma (G-1) SNDM / Proliferative Endometrium SNDM & $1.89 \pm 0.60$ \\
\hline AH/EIN SNDM/ Proliferative Endometrium SNDM & $1.61 \pm 0.37$ \\
\hline AH/EIN SNDM/ Hyperplasia without atypia SNDM & $1.48 \pm 0.42$ \\
\hline Endometrioid carcinoma (G-1) SNDM/ AH/EIN SNDM & $1.05 \pm 0.22$ \\
\hline Endometrioid carcinoma (G-1) SNDM/ Hyperplasia without atypia SNDM & $1.74 \pm 0.52$ \\
\hline Hyperplasia without atypia SNDM /Proliferative Endometrium SNDM & $1.11 \pm 0.29$ \\
\hline
\end{tabular}




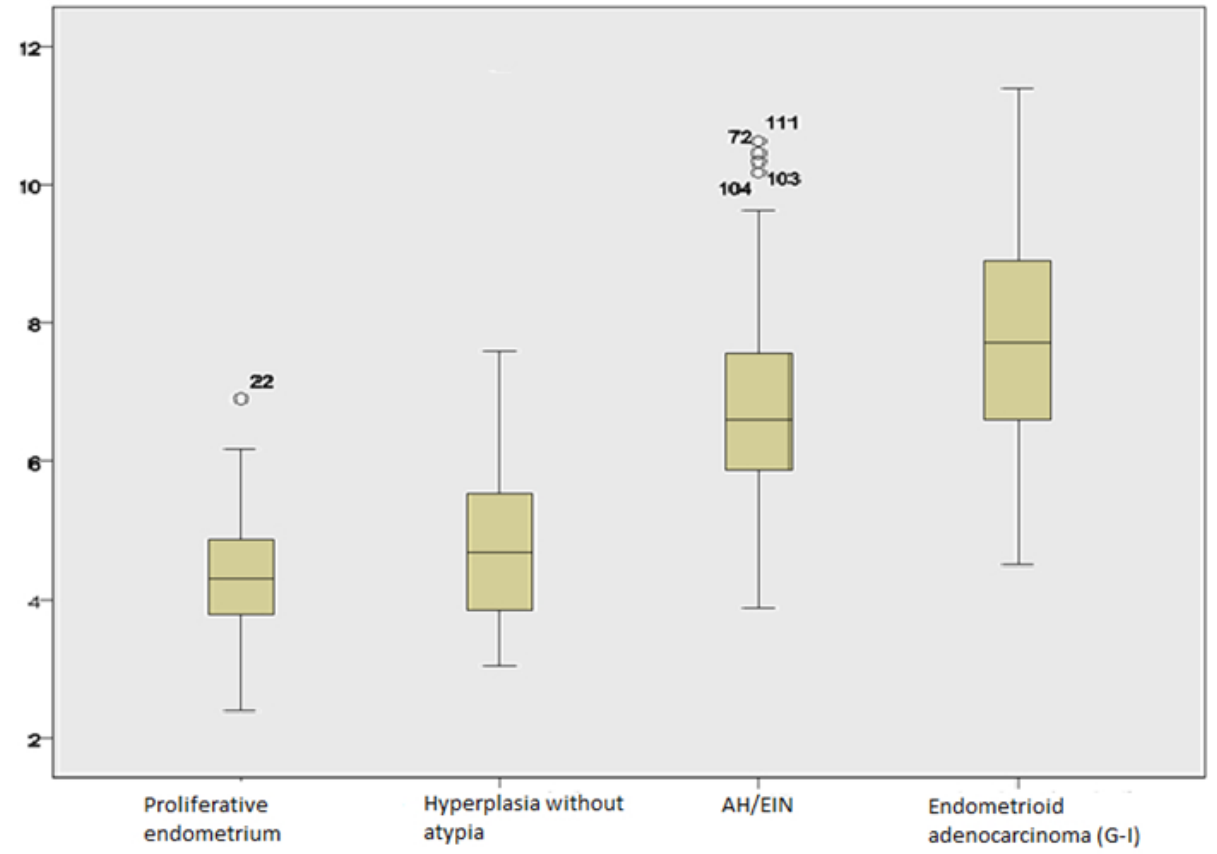

Figure 1. Nucleus diameter values. 


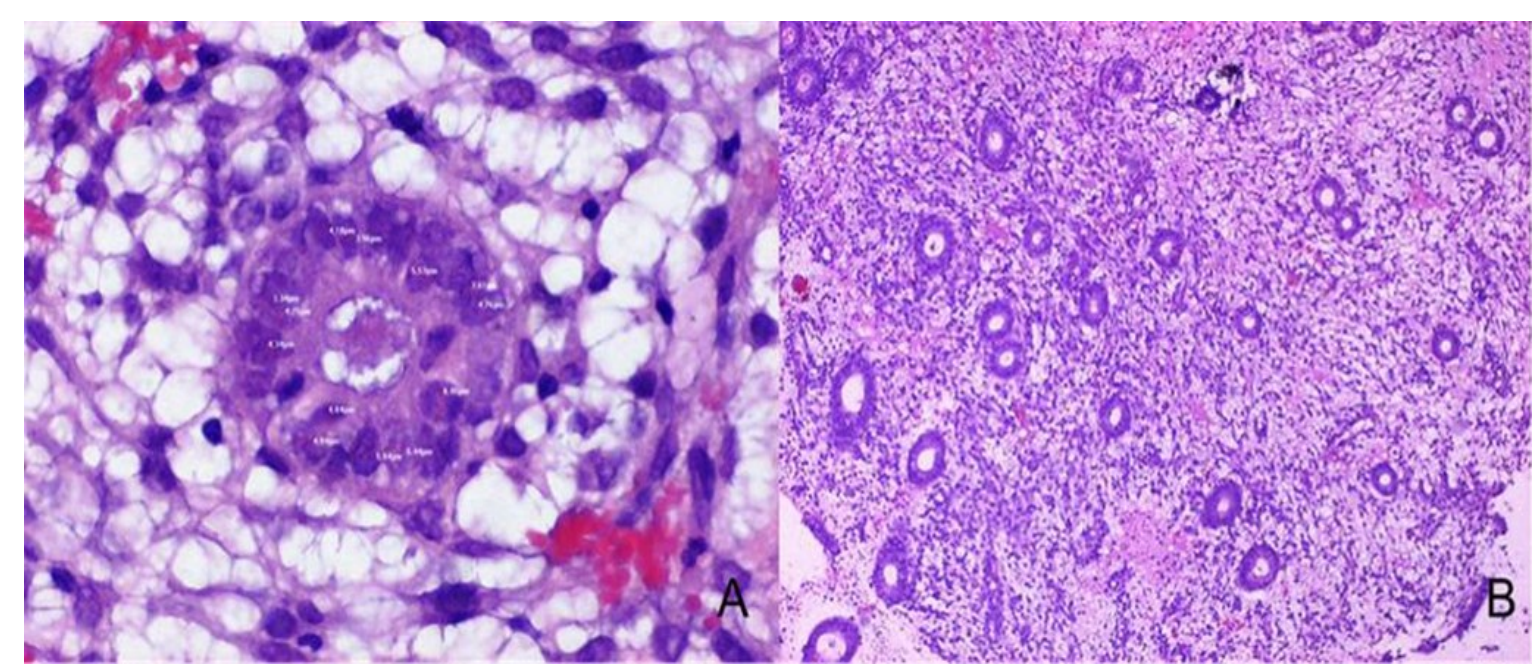

Figure 2. Images of proliferative endometrium H\&E stain (A-B) and shortest nucleus diameter SND measurement (400X) (A). 


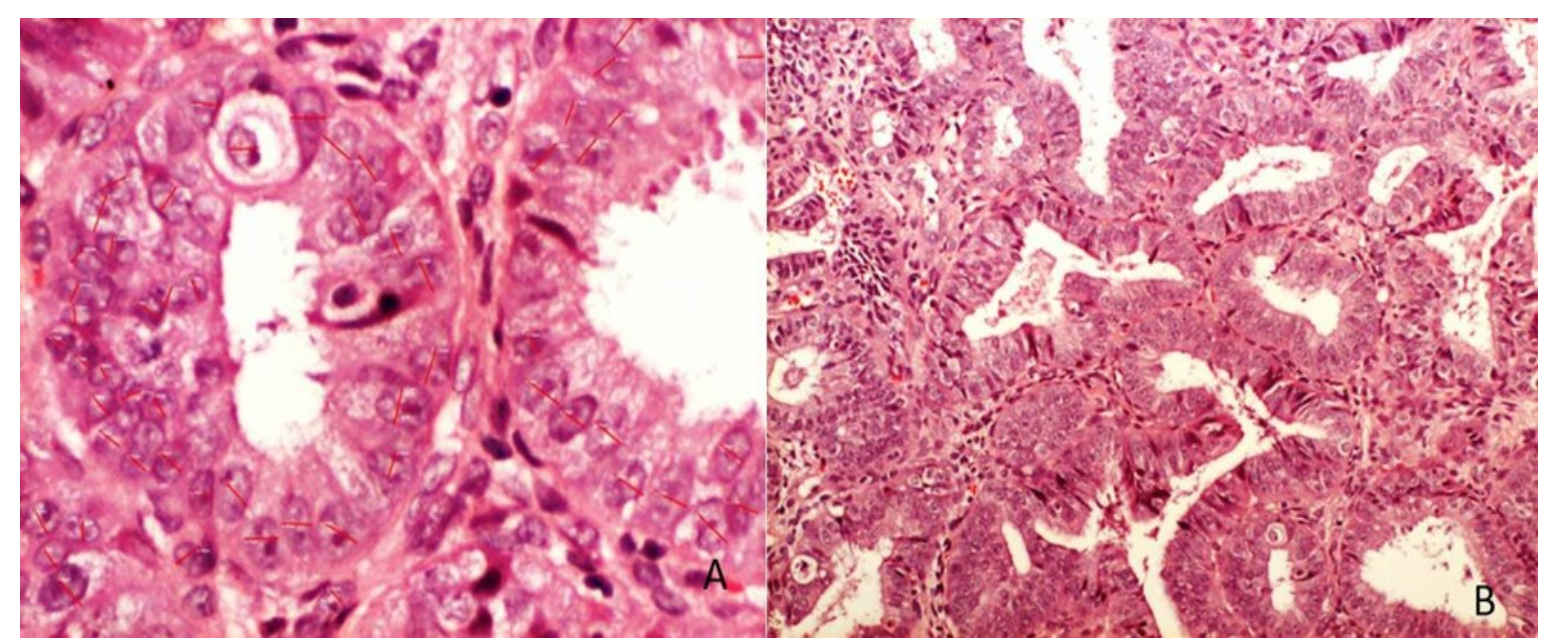

Figure 3. Images of endometrial hyperplasia with atypia H\&E stain (A-B) and shortest nucleus diameter SND measurement (400X) (A). 